DOI: $10.1515 /$ abcsj-2015-0008

\title{
Shadows Between the Signs
}

DAVID BRIAN HOWARD

Nova Scotia College of Art and Design University

\begin{abstract}
The following experimental text is drawn from my most recent research project War Machines: Utopia and Allegorical Poetics in the Twenty-First Century. The project is an adaptation of the allegorical poetics developed by the French poet Charles Baudelaire in his scathing attacks on the sweeping transformation of Paris being conducted by Napoleon III's right-hand man, Baron Haussmann. This small excerpt from my new book is a demonstration of my critical and poetical re-framing of Benjamin's work that orients itself more towards the overlooked elements of Benjamin's Marxism, as well as his "weak messianic" perspective, in order to re-assert a more radical orientation of his poetics and critical method with the utopian perspectives found in the work of that other great Marxist outlier of the twentieth century, Ernst Bloch, especially as outlined in his book, The Principle of Hope. Thus, unlike the postmodern appropriation of Baudelaire and Benjamin, I want to propose the possibility of bridging the gap between allegorical poetics, Marxism, and utopianism once again as a rigorous, critical option in the twenty-first century.
\end{abstract}

Keywords: modernity, progress, agency of language, recognizability, liberal terror, corporate fascism, totality, subjectivation, negative ideal of democracy

The following experimental text is drawn from my most recent research project War Machines: Utopia and Allegorical Poetics in the Twenty-First Century. The project is an adaptation of the allegorical poetics developed by the French poet Charles Baudelaire in his scathing attacks on the sweeping transformation of Paris being conducted by Napoleon III's right-hand man, Baron Haussmann. Baudelaire's insights into the nature of the modern urban environment proved inspirational to the German 
critic and writer, Walter Benjamin, especially in his most extensive piece of research, The Arcades Project, which remained uncompleted by the time of his suicide in the French-Spanish border town of Port Bou in 1940. Subsequent generations of scholars, especially noted North American scholars and critics like Craig Owens and Daniel Crimp, have drawn upon the fragmented and incomplete husk of Benjamin's masterwork to develop a mode of artistic analysis that exerts a particular interpretative and, I would argue, conservative pull on Benjamin's multilayered and radical vision. In their framing of Benjamin's work, they have emphasized a profoundly postmodern bias that avoided Benjamin's complex theoretical engagement with Marxism as well as important elements of the Jewish theological tradition that Benjamin had developed in dialogue with his long-time friend and renowned scholar of the Kabbalah, Gershom Scholem. This small excerpt from my new book is a demonstration of my critical and poetical re-framing of Benjamin's work that orients itself more towards the overlooked elements of Benjamin's Marxism, as well as his "weak messianic" perspective, in order to reassert a more radical orientation of his poetics and critical method with the utopian perspectives found in the work of that other great Marxist outlier of the twentieth century, Ernst Bloch, especially as outlined in his book, The Principle of Hope. Thus, unlike the postmodern appropriation of Baudelaire and Benjamin, I want to propose the possibility of bridging the gap between allegorical poetics, Marxism, and utopianism once again as a rigorous, critical option in the twenty-first century.

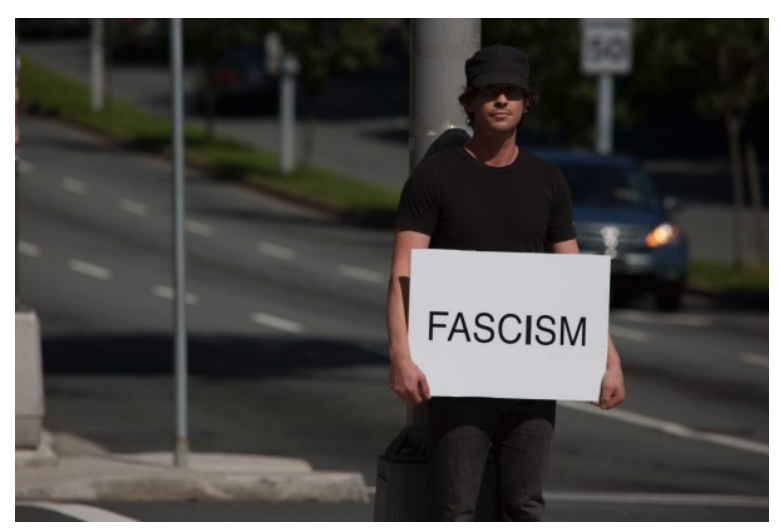


Photograph from "Words! Words!" This was a combined text and performance piece collaboration between Halifax artist Scott Saunders and myself. Angela Penton and Scott Saunders (above) were the performers in the project shot in late August, 2014. Photographs by Todd McLean.

"The problem of fascism today cannot simply be addressed as that of the potential or variable return and reconstitution of fascism, as if fascism had ever, or could ever, 'disappear', only to return and be made again, like some spectral figure from the past."

(Brad Evans \& Julian Reid, Guattari, eds., Deleuze \& Fascism: Security: War: Aesthetics. New York and Milton Park, Abingdon, Oxfordshire: Routledge, 2014. 1.)

"In reality, National Socialism involved the aspirations to destroy communism in order to build a massive empire that would insulate Germany from the vicissitudes of global capitalism; there was nothing remotely conservative about the aim. Hitler presented his anticommunism not as a military crusade against a great power, but as concern for the bottom line. German businesses and the full bellies of the electorate. In spring 1933, as the Soviet introduction of collective agriculture starved millions of peasants, Hitler used the specter of hunger to discourage Germans from voting for the Left. When he spoke at the Berlin Sportpalast of "millions of people being starved," he was appealing to the middle classes and their fears. When he continued by saying that Soviet Ukraine "could be the grain silo of the entire world," he was speaking to his Nazi followers. He veiled one sense of Lebensraum, the bloody conquest of habitat, behind the other, the promise of physical comfort."

(Timothy Synder, Black Earth: The Holocaust as History and Warning. New York, NY: Duggan Books, 2015. 43.) 
"We are in the middle of the night. I once tried to combat it with words ... At the time I learned that whoever fights against the night must move its deepest darkness to deliver up its light and that words are only a way station in this major life struggle: and they can be the final station only when they are never the first ..."

(Walter Benjamin, Correspondence 1910-1940, (1940), in Stephen Polsky, Walter Benjamin's Transit: A Destructive Tour of Modernity. Bethesday, Dublin, and Palo Alto, CA: Academica Press, 2010. 34.)

"Let the sun shine / the world is ours."

(Monique Wittig (David Le Vay, Translator), Le Guérillères. Urbana, and Chicago, Ill: University of Illinois Press, 2009. 97.)

"The sun is rising, feel it: the air smells fresh.

I cannot look in the sun's face, its brightness blinds me,

but from my own shadow becoming distinct

I know that now at last

it is beginning to grow light."

(Marge Piercy, "Outcome of the Matter: The Sun," in (Ruby Rohrlich and Elaine Hoffman Baruch, Editors), Women in Search of Utopia: Mavericks and Mythmakers. New York, NY: Schocken Books, 1984. 289.)

\section{"THE DEVIL}

Contemplate the sun! From its surface leap vast jets of flame, casting forth sparks that disperse beyond to become worlds hereafter; and further than the last, far beyond those deeps where thou seest only night, whirl other suns, - and behind them others again, and beyond those yet others, without end ...

\section{ANTHONY}

Enough! Enough! I fear! — I will fall into the abyss. 


\section{THE DEVIL}

pauses and rocks Anthony gently in the midst of space:

Nothingness is not - there is no void! Everywhere and forever bodies move upon the immovable deeps of space. Were there boundaries to space, it would not be space, but a body only: it is limitless!

\section{ANTHONY}

Stupefied by wonder:

Limitless!

\section{THE DEVIL.}

Ascend skyward forever and forever, - yet thou wilt not attain the summit. Descend below the earth for billions of billions of centuries; never wilt thou reach the bottom. For there is no summit, there is no bottom; there is no Above, no Below - there is no end. And Space itself is comprised in God, who is not a portion whereof of such or such a size, but is Immensity itself!"

(Gustave Flaubert, The Temptation of St. Anthony. London and New York, NY: Penguin Classic, 1983. 166-167.)

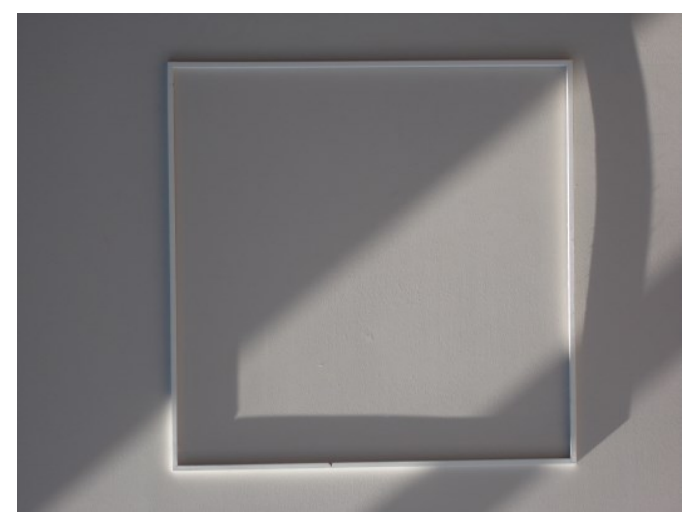

Peter Kolisnyk, "Untitled," 1976 (Canadian). The work is composed of three equal sized painted steel squares. All photographs by the author. Private Collection of Vivian and David Howard. 
"The artist is veracious when he puts into the work its absolute negation, to the same extent that the war machine he is propelling becomes effective through the cooperation of the reader, who becomes what he is by enduring it as a passion and assuming it as a crime. Beauty as the mask of hatred is that concerted unity of strategems which, patiently reconstituted by the reader, finally blinds him to its cold clarity. But the truth of that beauty is that it has a hold over its public; or, if you will, it is outside it because the reader can reconstruct it only by constructing himself as he is. This reader was not targeted either as a future reader or as a representative of humanity; the work meant to be a realm of the sun. But it conferred his ontological status when it found him; since he is transformed into himself in order to understand the work, and with no explicit motive but the search for aesthetic pleasure through the retotalization of this totalized discourse, he is its truth, that is, he makes it the means for becoming what he is."

(Jean-Paul Sartre (Carol Cosman, Translator), The Family Idiot, Gustave Flaubert, 1821-1857, Volume 5. Chicago and London: The University of Chicago Press, 1993. 310-11.)

"And while she was speaking, I saw the sun - not face to face, but where it enamelled the iron weathercock on the house opposite with tawny gold. And as the world is only a sundial of innumerable aspects, to see this was enough to know that in the square at Combray, the draper's shop, its awning let down because of the heat, was even then about to close for the interval of high mass, that the draper who had just changed into his Sunday coat was showing customers, amid a smell of brown holland, the latest thing in handkerchiefs, keeping his eye on the clock meanwhile, and that the market sellers were busy laying out their eggs and poultry while there was still no one about in the front of the church except that lady in black who in a country town may be seen slipping out of church at any time of day. But now it was not this that the enamel of bright sunlight on the weathercock of the opposite houses made me want to see again." 
(Marcel Proust (Trans. Syliva Townsend Warner), On Art and Literature. New York, NY: Caroll \& Graf Publishers, 1984. 83.)

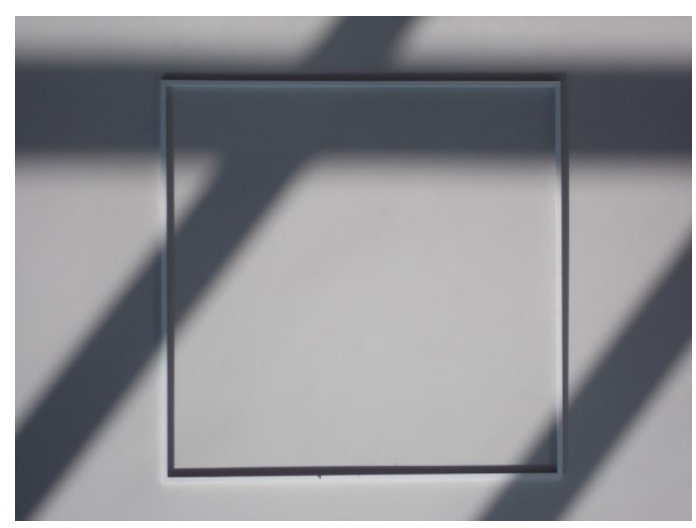

"The Sun arises in the East

Clothd in robes of blood \& gold

Swords \& spears \& wrath increast

All around his bosom rolld

Crowned with warlike fires \& raging desires"

(William Blake (David V. Erdman, Editor), "Day," in The Complete Poetry \& Prose of William Blake: New York, NY: Random House: 1984. 473.)

"You filled my sky and burned me like the sun."

(Marge Piercy, He, She and It. New York, NY: Fawcett Books, 1993. 238.)

"I rubbed my eyes almost out to see if I was really awake. It was morning's beginning: the sun was slowly but steadily rising with the stars that were with it when this world was and is wholeness. My heart, exalted, quivered.

'How could I know whether my heart had any right to be so exalted: to dance, prance, and glance in play? How could I know if what I 
was seeing was real? How could I know if I was real? How could I know? I know that I saw because seeing is knowing. Necessarily I knew then as I know now. If I was dreaming, I am dreaming', concluded the night."

(Kathy Acker, Don Quixote. New York, NY: Grove Press, 1986. 184.)

"Come, see: the Tree of Life holds together [ahid] from above to below and this sun that shines on all, its light begins from the top and spreads in the trunk of the tree [be-gufa de- 'ilana] in a straight path. Two sides are held together in her, one to the North and one to the South, and one to the Right and one to the Left. When the sun shines, as was said, from the trunk of the tree, strength goes to the Right arm that shines by its strength, and from its strength, the Left shines and is included in the light."

(David Greenstein, Roads to Utopia: The Walking Stories of the Zohar. Palo Alto, CA: Stanford University Press, 2014. 61.)

"Horizon is always already there of a future which keeps the indetermination of its infinite openness intact (even though this future was announced to consciousness). As the structural determination of every material indeterminacy, a horizon is always virtually present in every experience; the anticipated unity in every incompletion. The notion of the horizon converts critical philosophy's state of abstract possibility into the concrete infinite potentiality secretly presupposed therein. The notion of horizon thus makes the apriori and the teleological coincide."

(Jacques Derrida, Edmund Husserl's Origin of Geometry: An Introduction, in Brad Evans, Liberal Terror. New York, NY: Polity Press, 2013. 167.)

"The philosopher is always a stranger, clothed in his new thoughts." 
(Alain Badiou and Slavoj Žižek (Peter Engelmann, Editor, and Trans. Peter Thomas and Àlberto Toscano), Badiou \& Žižek: Philosophy in the Present. Cambridge and Malden, MA: Polity Press, 2009. 23.)

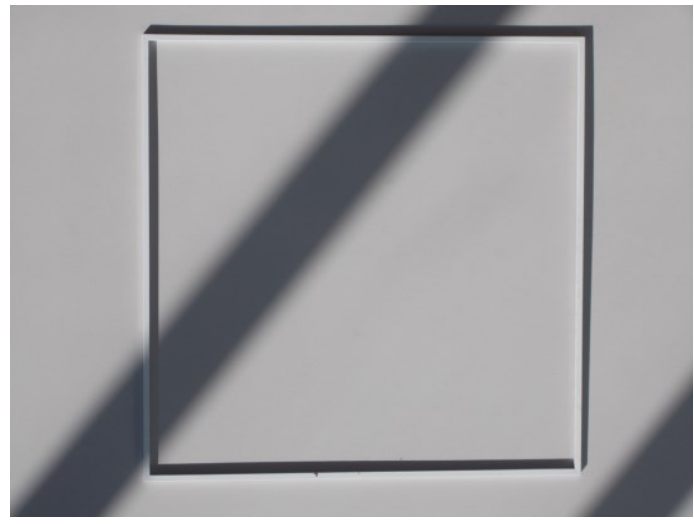

"And as it usually happens when the sun beings to show his beams, or when after a sharp winter the spring breathes afresh on the earth, all things immediately get a new face, new color, and recover as it were a certain kind of youth again: in like manner, by but beholding me you have in an instant gotten another kind of countenance; and so what the otherwise great rhetoricians with their tedious and long-studied orations can hardly effect, to wit, to remove the trouble of the mind, I have done it at once with my single look."

(Desiderius Erasmus (Trans. John Wilson), The Praise of Folly. Rockville, MD: Arc Manor, 2008. 9.)

"The Dark Dreamer had already shaved and dressed in a simply cut shirt and pants of a soft gray..."

(Suzy Charnas, Walk to the End of the World. Berkley, CA: Berkley Publishing Group, 1979. 218.) 
"But then, as recompense [Entgelt], there will come the joyful morning of other days and climes, when he shall see, even before the light has broken, the Muses come dancing by him in the mist of the mountains, when afterwards, if he relaxes quietly beneath the trees in the equanimity of his soul at morning [Gleichmaass der Vormittags-seele], good and bright things will be thrown down to him from their tops and leafy hidingplaces, the gifts of all those free spirits who are at home in mountain, wood and solitude and who, like him, are, in their joyful, now thoughtful way, wanderers and philosophers."

(Friedrich Nietzsche, Human All Too Human, in James McFarland, Constellation: Friedrich Nietzsche and Walter Benjamin in the Now-Time of History. New York, NY: Fordham University Press, 2014. 176-7.)

"Bringing my fantasies into the real world frightened me very much. It's not that they were bad in themselves, but they were Unreal and therefore culpable; to try and to make Real what was Unreal was to mistake the very nature of things; it was a sin not against conscience (which remained genuinely indifferent during the whole affair) but against Reality, and of the two, the latter is far more blasphemous. It's the crime of creating one's own Reality, of 'preferring oneself' as a good friend of mine says. I knew it was an impossible project.”

(Tucker Farley, "Realities and Fictions: Lesbian Visions of Utopia," in (Ruby Rohrlich and Elaine Hoffman Baruch, Editors.), Women In Search of Utopia: Mavericks and Mythmakers. New York, NY: Schocken Books, 1984. 233.)

"Sun: agency of language since it is the 'crown' of rhythmic thrust, limiting structure, paternal law abrading rhythm, destroying it to a large degree, but also bringing it to light, out of its earthy revolutions, to enunciate itself. Inasmuch as the 'I' is poetic, inasmuch as it wants to enunciate rhythm, to socialize it, to channel it into linguistic structure if only to break the structure, this 'I' is bound to the sun. It is a part of this agency because it must master rhythm, it is threatened by it because solar 
mastery cuts off rhythm. Thus, there is no choice but to struggle eternally against the sun; the 'I' is successively the sun and its opponent, language and its rhythm, never one without the other, and poetic formulation will continue as long as the struggle does."

(Julia Kristeva (Ed. Leon S. Rudiez and Trans. Thomas Gora, Alice Jardine, and Leon S. Rudiez), Desire in Language: A Semiotic Approach to Literature and Art. New York, NY: Columbia University Press, 1982. 29.)

"Whatever the mind seizes, the rays of light which are awakened in it by this exploration amongst the fundamental notions of things, that is the assistance which Theory affords the mind. Theory can give no formulas with which to solve problems; it cannot confine the mind's course to the narrow line of necessity by Principle set up on both sides. It lets the mind take a look at the mass of objects and their relations, and then allows it to go free to the higher regions of action, there to act according to the measure of its natural forces, with the energy of the whole of those forces combined, and to grasp the True and the Right, as one single clear idea, which, shooting forth from under the uniting pressure of all these forces, would seem to be rather a product of feeling rather than reflection."

(Carl von Clausewitz, On War: Oxford and New York, NY: Oxford University Press, 2007. 665.)

"The black sun is an inversion of Tiphereth, the Sun of the Tree of Life, its demonic mirror in the Klipoth. This is the sun in the $12^{\text {th }}$ House, the Sun of Unconsciousness in the House of the Dead."

(Rajeev S. Patke, “Benjamin's Aura: Steven's Description Without Place," in (Lance Bell and David Brottman, and Gerhard Richter), Benjamin's Blind Spot: Walter Benjamin and the Premature Death of Aura. New York, NY: Institute of Critical Inquiry, 2001. 88.) 


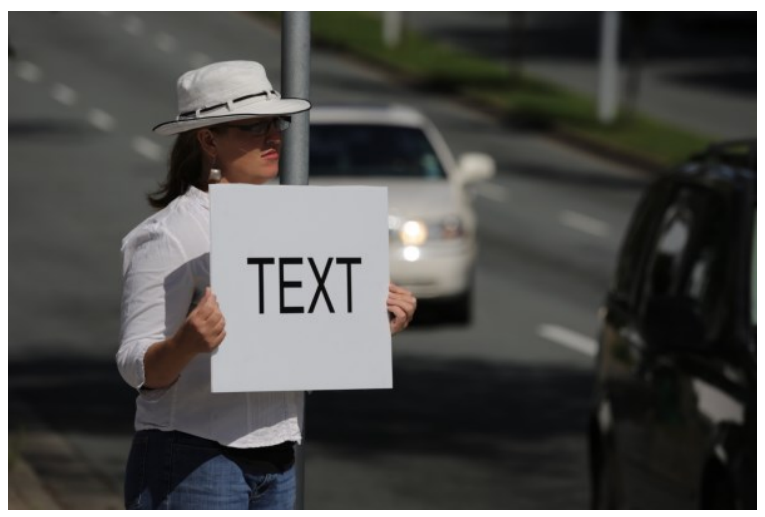

"This alliance with texts redeems us because, while human beings have long been divorced from God's perspective, the signs by which we perceive the world have not. Although we are banished from a God's eye view, our textual allies are not. If there is no 'hope' for us, we can partake in an alliance with that which has never been excluded, never truly broken by the fall and the onrush of hubris and time and history that it produced. This is what allows mourning, the sadness of Trauerspiel (mourning plays), to lead to a 'progressive deepening of its intention'."

(James R. Martel, Textual Conspiracies: Walter Benjamin, Idolatry, \& Political Theory. Ann Arbor, MI: The University of Michigan Press, 2013. 232.)

"“...the sun as goddess, instead of as a god, is a rare and precious survival from an archaic, apparently once widely diffused, mythological context. The great maternal divinity of Saudi Arabia is the feminine sun, Ilat. The word in German for the sun (die Sonne) is feminine. Throughout Siberia, as well as in North America, scattered stories survive of a female sun.' (Joseph Campbell, The Hero with a Thousand Faces 211)."

(Robert D. Gowdy, The Text and the Other: Toward the Caesura of the Unconscious and Narrative. Shelbyville, KY: Wasteland Press, 2008. 114.) 
"And if suffering is a sun, it is because its rays immediately traverse distances without annulling them. This is precisely what we have observed in the case of the partitioning of contiguous things: contiguity does not reduce distance to the infinitesimal but affirms and even extends a distance without interval, according to an ever astronomical, ever telescopic law that governs the fragments of disparate universes."

(Gilles Deleuze (Trans. Richard Howard), Proust and Signs: The Complete Text. London: The Athlone Press, 2000. 144.)

"Human freedom means the right to take part in the creation of laws for the better government and perfection of man; it means that man and woman are born equal, are created to work hand in hand for the greater happiness of mankind ... By the acknowledgement of this principle you have laid the train which, when fired, will put an end to immorality and social wrongs, which will make evil unpleasant to perform, and which will degrade the performer to the position of a leper ... a day of darkness has sunk to rise no more, and one of brightness, and promise, and fair hope has arisen to cheer us along the glorious path of reform."

(Lady Florence Dixie, Gloriana, or, the Revolution of 1900, in (Ed. Libby Falk Jones and Sarah Webster Goodwin), Feminism, Utopia, and Narrative. Knoxville, TN: University of Kentucky Press, 1990. 61.)

"That day, while the sun was still full, we arrived at the edge of the pond that de Sade had named. This was the day the Germans had invaded Vienna. Society turned to war."

(Kathy Acker, My Mother: Demonology. New York, NY: Random House, 1993. 261.)

"(Defenseless, unredeemed light, you who burn in the inhospitable world, between the 
wicked furrows and gates fixed in the criminal mind ... you are in the blind corner or the emptiness of rooms, or in the lament of the battle-field glare ... the hypocritical beacon lights up the troops, but you exist and search for your brothers.)"

(Signoribus, Belliche, in Giorgio Agamben (Trans. Daniel Heller-Roazen), The End of the Poem: Studies in Poetics. Stanford, CA: Stanford University Press, 1999. 128.)

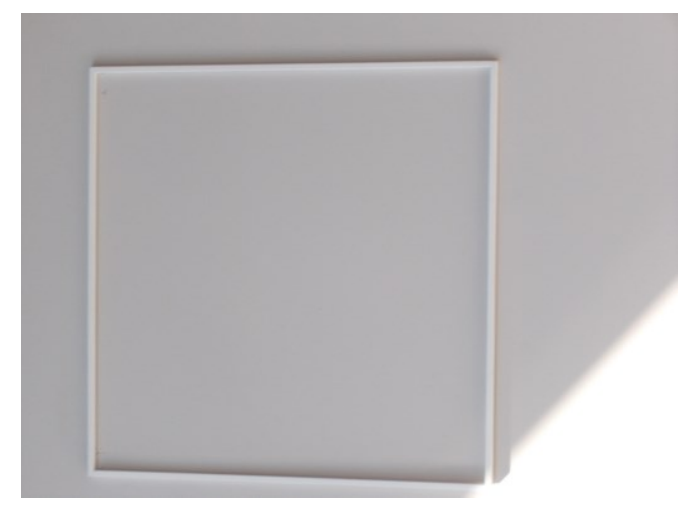

\footnotetext{
"We are bored with the city, there is no longer any Temple of the Sun."

(Ivan Chtcheglov, in McKenzie Wark, The Beach Beneath the Street: The Everyday Life and the Glorious Times of the Situationist Internationale. New York, NY: Verso, 2011. 19.)
}

"PAUSING INTERMITTENTLY under the merciless sun, Cesareo Dominguez desperately scanned the desert near the Arizona border for twenty-one consecutive days. In a well-known migrant corridor, just south of Pima County, his search came to a tragic end when he discovered what he hoped he wouldn't, the lifeless body of his daughter, Lucresia. She had 
made a desperate attempt to cross Mexico without papers, in order to reunite with her husband now living in the United States. On the other side of the same stretch of desert, right-wing vigilante squads calling themselves the Minutemen have begun patrols along the U.S.-Mexico border. Sporting fatigues, a small arsenal, and paramilitary bravado, their migrant hunting expeditions are designed to open a new front of the 'war on terrorism' by portraying the 'porous border' as a threat to national security and 'American culture'."

(J. Akers, "Vigilantes at the Border: The New War on Immigrants," in International Socialist Review, 43 (2005), in Michael J. Shapiro, Studies in Trans-Disciplinary Method: After the Aesthetic Turn. Oxon and New York, NY: Routledge, 2013. 132.)

" - The recognition of the fragmentation of historical reality is the dawn ... of an identity, a world-wide consciousness. Just as we could say: 'my lived time is mine and I'm conscious of it because there are interruptions.' I would say: 'we are going toward the pure State because there is an infinite fragmentation of inter-state conflicts.' In other words, we're going toward the common consciousness that we are all earthlings, identical - with all the fearsome and monstrous things that presupposes."

(Paul Virilio and Sylvére Lotringer, Pure War. Cambridge, MA: The MIT Press, 2008. 37.)

"This blemished radiance ... this night-stung dawn

Is not the dawn we waited for..."

(Faiz Ahmed Faiz, Pakistani poet, in Vandana Singh, The Woman Who Thought She Was a Planet. Shahpur Jat, New Delhi: Zubaan, 2009. 81.)

"Here we see a verticalized 'terrain of particles' stratified into 'a syntax of splits and ruptures,' a granitic structure in which the suffix -ing can beome a subject of the definite article, and -tive and -tions operate in 
the 'syntax of splits and ruptures' that words and rocks (both inhabiting a 'terrain of particles') share. Such a radical collapse of structure into sequence creates the 'crytstalline' axes of 'space' of this poem, and 'space' becomes the text's overriding single metaphor, cast into the 'continuous series' of the poems."

(Michael Golston, Poetic Machinations: Allegory, Surrealism, and Postmodern Poetic Form. New York, NY: Columbia University Press, 2015. 86.)

"This morning, words loot the flowers, and sentences crawl in the mud like worms."

(Edmond Jabès, The Book of Questions. Middleton, CT: Wesleyan University, 1976. 171.)

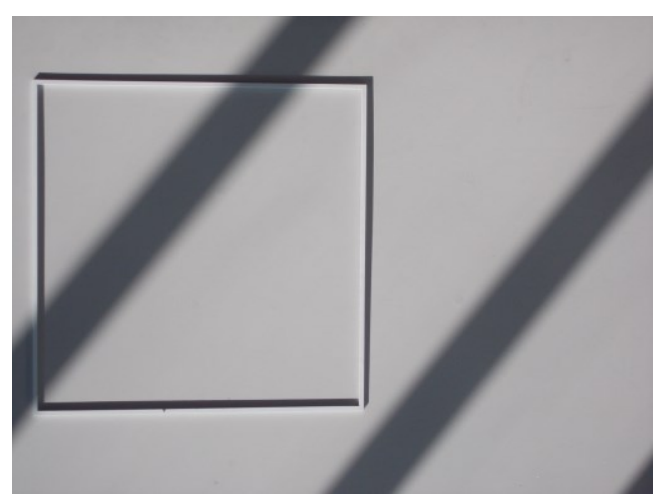

"It is not that what casts its light in what is present, or what is present its light on what is past; rather, image is that wherein what has been comes together in a flash with the now to form a constellation. In other words: image is dialectics at a standstill. For while the relation of the present to the past is purely temporal, the relation of what-has-been to the now is dialectical: not temporal in nature - that is, not archaic - images. The image that is read - which is to say, the image in the now of its 
recognisability - bears to the highest degree the imprint of the perilous critical moment on which all reading is founded."

(Walter Benjamin (Ed. Rolf Tiedemann and Howard Eiland, Trans. Kevin McLaughlin), The Arcades Project. Cambridge, MA: The Belknap Press of the Harvard University Press, 2002. 463.)

"The sun comes up with unbelievable force. I shudder under the rays like a vampire caught far from my coffin. All around us are the unmarked spots where the last dramas of the dying take place. One man went down a mile south of the Interstate. He set fire to a tree in hopes that the smoke would bring help. They found his body...

We walk on. We must have walked on. But there is no memory of this. So we walk on."

(Charles Bowden, Blue Desert, in (Ed. Tom Miller), Writing on the Edge: A Borderlands Reader. Tucson, AZ: University of Arizona Press, 2003. 219.)

"I am Daybreak, ultimately tired / from having risen to wage war with myself, / as there are no more wars more exhausting than this. / For before you stirrup your war-horse, you know / that the immense shadow of the vulture with its spread-out wings / has enveloped the battlefield. / And fate has buried you as a blood-stained melted thing. / And there is no way out / from defeat and death."

(Ahmad Shamlu, "The Reward," qtd. in Jason Mohaghegh, "The Excilic Imagination," in (Ed. May Telmissany and Stephanie Tara Schwartz), Counterpoints. Cambridge, MA: Cambridge University Press, 2007. 114.)

"This text certainly invokes a continuity and a totality, but the essential point is to know where these are elaborated - neither in the viewpoint nor in the things seen, but in the transversal, from one window to another." 
(Deleuze, Proust and Signs 185.)

"das vorletzte Wort."

"Almost the last word."

(Theodor W. Adorno, Minima Moralia, qtd. in Richter, Thought Images: Frankfurt School Writers' Reflections from Damaged Life. Stanford, CA: Stanford University Press, 2007. 190.)

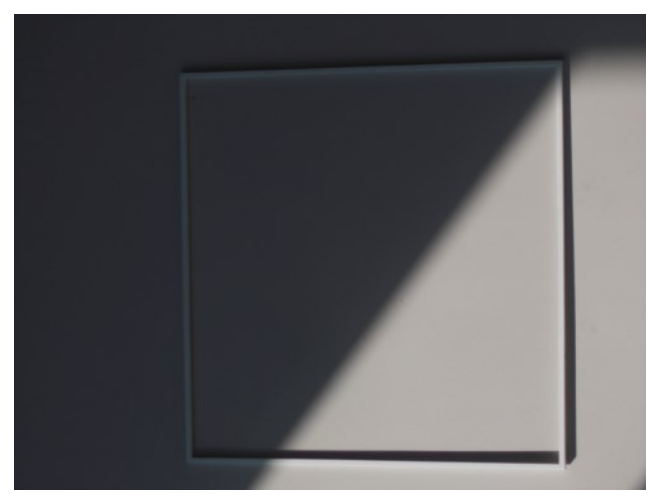

"There was the observer who wrote the following in his notebook: 'Progress, and all the phenomena that surround it, seems to participate intimately in that law of acceleration, general, cosmic, and centrifugal which drags civilization to "maximum progress," so that after that comes the fall? That's the problem: we cannot know if this society will destroy itself utterly or will simply encounter a sudden interruption and then a resumption of its forward motion.' And then: 'The Sun would diminish its effects upon the Earth, provoking the beginning of a new ice age that could last for ten thousand years.' Ten thousand years was a lot, and it was frightening. That's what happens when someone chooses, for fear of the dark night, to live in the superficial light of day. Yes, the supernatural, divine or demonic, has been a temptation since Egypt, passing through the Middle Ages to the dime-store mysteries of today." 
(Clarice Lispector, "Where you were at Night," in Clarice Lispector, Soulstorm. New York, NY: New Directions, 1989. 128.)

"The Grid's two-dimensional discipline also creates undreamt-offreedom for three-dimensional anarchy. The Grid defines a new balance between control and de-control in which the city can be at the same time ordered and fluid, a metropolis of chaos."

(Rem Koolhaas, Delirious New York: A Retroactive Manifesto for Manhattan, in Kenneth Goldsmith, Capital. London and New York, NY: Verso, 2015. 470.)

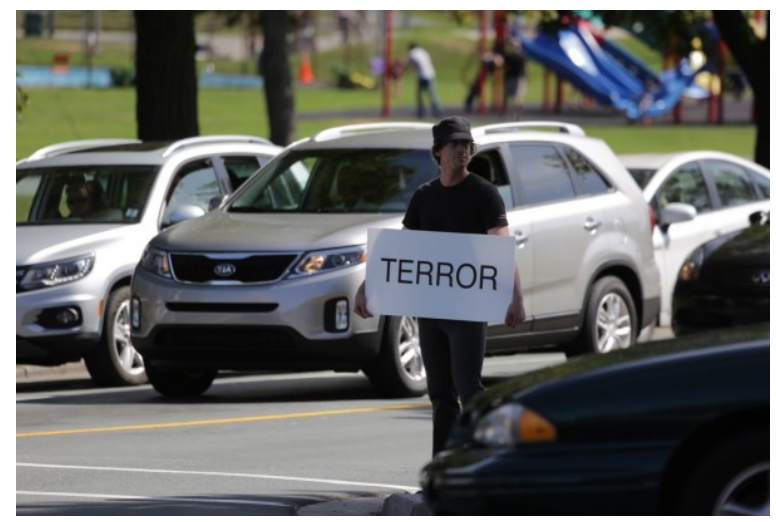

"Basically, the empty square shows that the structure is only a simulacrum and that, while it fabricates sense, the being that is proper to it - namely, the life that sustains the effect of sense - does not, in any way, enter into the sense so fabricated. For life (the One), being univocal, holds the equivocity of produced sense for a nonsense."

(Badiou, Deleuze 82-3.)

"I want to be clear that wanting utopian change is not enough to actually build livable spaces of sexual or other life-sustaining citizenships - dreaming of the future and executing well-honed political strategies that 
have concrete effects in people's lives are not the same thing. But as we can see in the rapid and brutal execution of neoliberal visions, it matters whether and how we imagine the future or there will indeed be no alternatives. Neoliberal policies and cultural shifts have their roots in utopian visions for a free-market society, which have intentionally or not resulted in the free-fall of the middle and working classes and the domestication of some radical movements. Criticism, even radical negativity, remains important in future-oriented work to ensure that our visions are committed to resisting the traps of our present time."

(Kaitlin Noss, "Queering Utopia: Deep Lez and the Future of Hope," Women's Studies Quarterly, Volume 40, Numbers 3 \& 4, 2012: 132-3.)

" $[\mathrm{T}]$ he very conditions that make the State or World war machine possible, in other words, constant capital (resources and equipment) and human variable capital, continually recreate unexpected possibilities for counterattack, unforeseen initiatives determining revolutionary, popular, minority, mutant machines. The definition of the Unsuspected Enemy testifies to this: 'multiform, maneuvering and omnipresent $\ldots$ of the moral, political subversive or economic order, etc.', the unassignable material Saboteur or human Deserter assuming the most diverse forms."

(Gilles Deleuze and Felix Guattari, A Thousand Plateaus, (1987), in Simon Glezos, The Politics of Speed: Capitalism, the State, and War in an Accelerating World. London and New York, NY: Routledge, 2012. 77.)

"The Manichean sun god, known as the Third Messenger (Neryosang) who lives in the sun and sets the sun and moon in motion, creating the changes of the season."

(Michael Palmer, "The Danish Notebook," in Michael Palmer, Active Boundaries: Selected Essays and Talks. New York, NY: New Directions, 2008. 131.) 


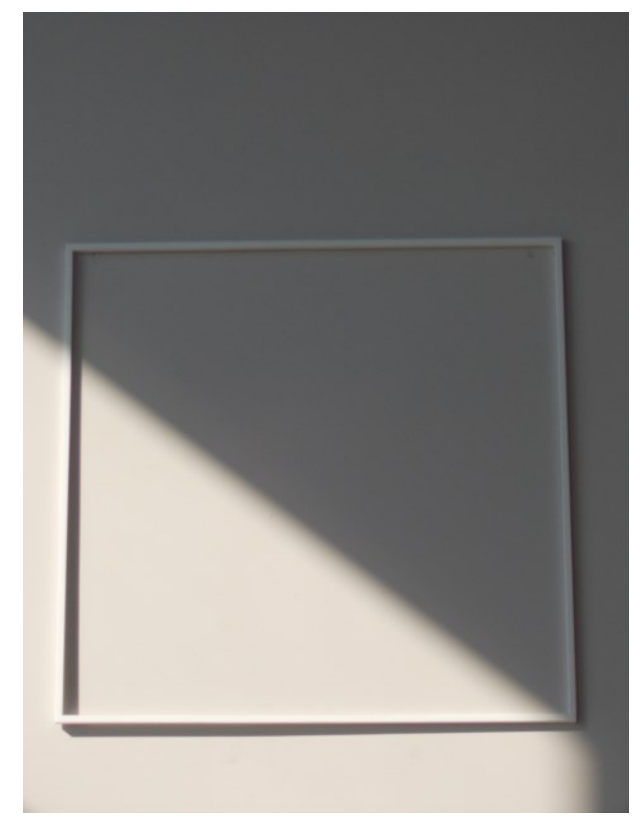

"Besides, it is well known that empire has been traveling from east to west. Probably her last and broadest seat will be America. Here the sciences and the arts of civilized life are to receive their highest improvement ... Elevated with these prospects, which are not merely the visions of fancy, we cannot but anticipate the period, as not far distant, when the AMERICAN EMPIRE will comprehend millions of souls, west of the Mississippi."

(Jedidiah Morse, The American Geography, 1789, qtd. in Richard Drinnon, Facing West: The Metaphysics of Indian-Hating and Empire-Building. Norman, Oklahoma: University of Oklahoma Press, 1997. 402.)

"American consciousness has so far been a false dawn. The negative ideal of democracy. But underneath, and contrary to this open ideal, the first hints and revelations of IT. IT, the American whole soul.

You have got to pull the democratic and idealistic clothes off American utterance, and see what you can of the dusk body of IT underneath. 
'Hence the masterless.'

Henceforth be mastered."

(D.H. Lawrence, "The Spirit of Place," in (Mary Ann Caws, Ed.), Manifesto: A Century of Isms. Lincoln, NB: University of Nebraska Press, 2000. 566.)

"New World

\section{A World of Villages}

The age that now dawned was one of almost explosive progress, explosive, yet controlled. Unlike the industrial revolution which is familiar to readers of this book, it was not dependent on the licentious economic individualism. Its energy was derived, of course, very largely from the self-assertive itch of able individuals, but the means of satisfying this craving were now in the main centrally planned and socially useful. Superficially at least I was able to grasp the material achievement of the race in this period, but its cultural life henceforth increasingly escaped me, out-arranging my comprehension."

(Olaf Stapleton, Darkness and Light, in (Gregory Claeys and Lyman T. Sargent, Eds.), The Utopia Reader. New York, NY: New York University Press, 1999. 363.)

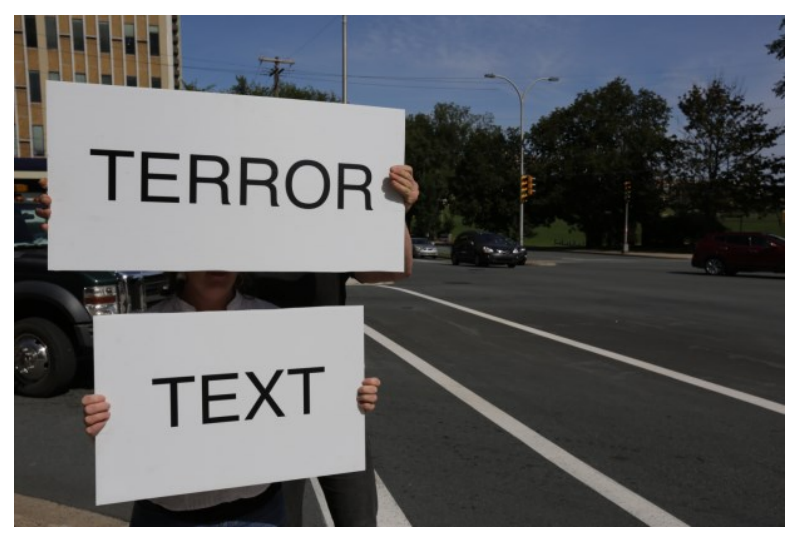


"The disappearance of the other major superpower with the collapse of the Soviet Union has, needless to say, profoundly changed the global order. If nothing else, it has removed the last remaining reality check on U.S. global ambitions. It could, of course, be argued that the removal of its principal adversary should have moderated the U.S. compulsion to achieve ever more massive global supremacy, and that it is hard to understand where the motivation now comes from, when the U.S. is already so clearly supreme. But, if anything, the absence of the Soviet Union has complicated the maintenance of U.S. hegemony over its allies. In any case, hyper-dominance creates a logic and momentum of its own. Unilateral global supremacy can never be achieved once and for all. It means moving the boundaries of warfare ever further beyond the reach of would-be challengers; and this requires constant revolutionizing of the means of war - which cannot then be left untested and unused."

(Ellen Meiksins Wood, Empire of Capital. London and New York, NY: Verso, 2005. 163.)

"As the sun rose in the East, Mao, clad in soldier's fatigues, stepped out onto the gallery of the famous gate ... Before him stood a youthful force setting out for revolution to the tune of 'The East is Red,' their battle hymn. No other country could mount the impressive displays of massed humanity organized during the cultural revolution, every human atom seemed fused with all the other human atoms in an exalted common dedication to Chairman Mao."

(Jack Luzkow, What's Left? Marxism, Utopianism, and the Revolt against History. Lanham, MD: UPA Publishing, 2006. 48.)

"We are all familiar with Hamlet's words about 'the linkage of times that collapsed,' which as a paraphrase renders the images of a breaking chain or string of beads. But in the literal sense, according to A. Ankiat's afterword in his Russian translation of the play, the original text 
says - 'the time is out of joint' (Act I, Scene 5). After which Hamlet states that he has 'to set it right.'

He is healing the time, reinventing it.

And it is Hamlet who, when asked what he is reading, replies:

'Words, words, words.'

Yet this is a trope - they are words, but they are different words."

(Viktor Shklosvky (Trans. Shushan Avagyan), Bowstring: On the Dissimilarity of the Familiar. Chapman, Dublin, and London: Dalkey Archive Press, 2011.314.)

\section{“THE CRUNCH EFFECT}

A comfort, that the sun rose

That first night the pathologists hadn't a moment's rest. They'd been joined by army colleagues. The autopsy tables were in constant use. Then, after the number of available tables were in constant use. Then, after the number of available personnel reached a peak, the pathologists who had been there from the beginning, and gone to get a nap, were returning to duty again, and the admissions became few and far between. Only parts of human beings, and soon after that nothing at all from the catastrophe scene even reached the green halls, the chilly autopsy rooms.

- How do you explain the fact that no cavities with survivors are being found? And also no intact corpses? In fact, very few parts of bodies, such as we usually get with major accidents.

It's the crunch effect, replies the New York Fire Department's senior structural engineer. This is no conference in session here: instead, an exhausted group from emergency services, ready for duty, but without a concrete task, is killing time in the big cafeteria.

Daybreak outside. It was that morning which on the TV showed a huge sun behind the artistically piled-up smoke and clouds of the other great 
buildings of the city, an image of self-confidence. A comfort, that the sun rose."

(Alexander von Kluge (Trans. Martin Chalmers), The Devil's Blind Spot: Tales From the New Century. New York, NY: New Directions, 2004. 19-20.)

"For me, [Slavoj Žižek], 1989 was not the end of utopias, as is commonly claimed, not the end of communism, but rather the unleashing of the great utopia of liberal capitalism, marked by Francis Fukuyama's 'End of History'. And September 11 is the answer to it; if it means anything at all, it means that this utopia is today dead. The Americans, I think, are paying the price in the meantime: look at American politics - it has been completely transformed. We don't have to believe their phrases about democracy anymore. They want to combine their world, their power to be able to intervene militarily in the world wherever they want, with new isolationism, new walls, etc. And democracy is defined in such a radically new way in this process that only its name remains."

(Alain Badiou and Slavoj Žižek, Badiou \& Žižek and Political Transformations: The Cadence of Change. Evansville, IN: Northwestern University Press, 2009. 96-7.)

"And after? With the Cold War receding and 'post-9/11' on the rise as a periodization of the present, does it make sense to speak of a perpetual interwar in referring to our own moment? To be sure, the prospect of a worldwide war that would both mobilize and target whole populations seems more remote than it once did. Other doomsday scenarios occupy us more urgently. Yet despite our not having plunged into global conflict since the Second World War, few populations have enjoyed an uncomplicated peacetime in recent years. In the global frame, the Uppsala Conflict Data Program reported thirty-three 'armed conflicts' - those in which at least one party is a state - as having occurred in 2013, the most recent reported year, alongside a much larger number of nonstate and one-sided conflicts. U.S. armed forces are deployed at present in 
over 150 countries, most of them in Middle Eastern combat zones associated with the 'war on terror'."

(Paul K. Saint-Amour, Tense Future: Modernism, Total War, Encyclopedic Form. Oxford: Oxford University Press, 2015. 311-312.)

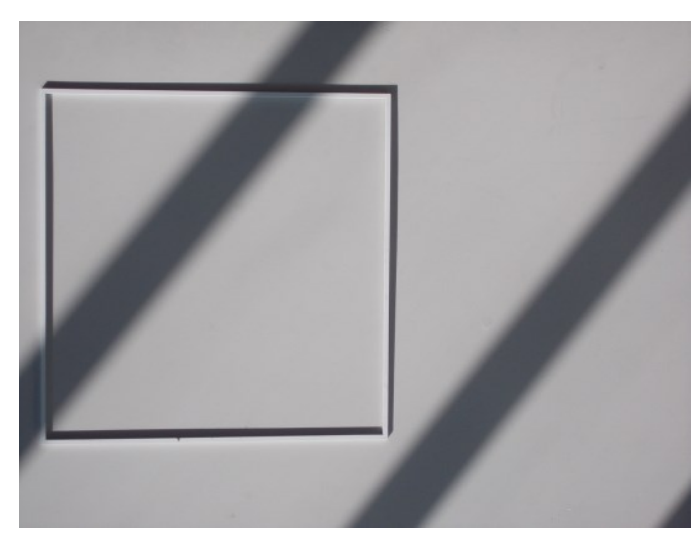

"Day was just breaking, and I looked out in amazement at the rows of uniform houses, which seemed the more run-down, the closer we got to the city center. In Moss Side and Hulme there were whole blocks where the doors and windows had been demolished. Views open up across the wasteland towards [what ...] had once been the hub of one of the nineteenth century's miracle cities."

(W. G. Sebald, The Emigrants, in (Ed. J. J. Long \& Anne Whitehead), W.G. Sebald - A Critical Companion. Edinburgh, Scotland: Edinburgh University Press, 2004. 63.)

"But in the meantime I would like to raise the question whether in the end the whole issue of the positive and the negative is inhabited by a pseudos, by something over-proportioned that for the sake of its abstractness allows what is most important to slip away. After all, utopia is the concrete rather than being itself a general theory or a concise 
instruction for praxis, and every truly saturate contemplation, to which conceptual being certainly belongs, is the guarantee of precisely what is ground up between the principles. Telling you, the artist, about this means carrying owls to Athens [Eulen nach Athen tragen] who begin their flight at dusk."

(Theodor W. Adorno, Minima Moralia, qtd. in Gerhard Richter, Thought-Images. Frankfurt School Writers' Reflections from Damaged Life. Stanford, CA: Stanford University Press, 2007. 157.)

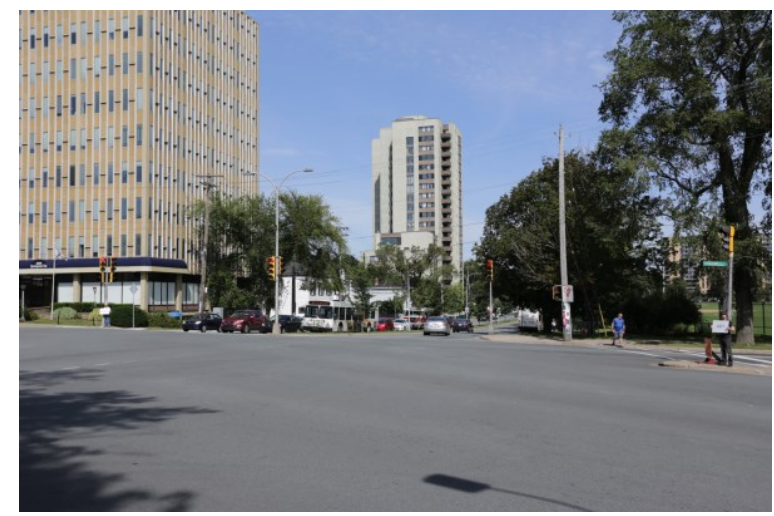

"What is the horizon in everyday perception that embodies the cosmogonic separation of Earth from Sky? The strange power of the horizon to distinguish these two regions from each other in the course of daily existence - a power to which we rarely attend as such - is the dynamic basis of the gap between Heaven and Earth. As painters know, it is anything but a mere 'horizon line,' the spatial equivalent of the time line; the experienced horizon is a central creative force in the field of visual perception, especially when beheld at the beginning or the ending of the day."

(Edward S. Casey, The Fate of Place: A Philosophical History. Berkeley and Los Angeles, CA: The University of California Press, 1998. 11.) 
"The essence of the 'current crisis' lies in the incapacity of capitalist forces to articulate the discursive and existentialist dimensions, in the impossibility of assembling ensembles of actualized economic, social, and technological flows and the virtual and incorporeal dimension of subjectivity production, existential territories, and universes of value. If the production of subjectivity is not part of a social field, a 'product,' a politics, a language, and so forth, we are faced, as is the case today, with a pathology of subjectivity (racist, xenophobic, individualist, confined to one's own interests, etc.). The watchwords concerning employment, fullemployment, wages, labor, the defense of the welfare state, and so on, which ought to be connected to subjectivity, do not lead to subjectivation processes, for they do not open onto new worlds, do not constitute optional matter for modern-day subjectivity."

(Maurizio Lazzarato, Signs and Machines: Capitalism and the Production of Subjectivity. South Pasadena, CA: Semiotext(e), 2014. 217.)

"What is the future, then? What is it that lies before us? Unactualized difference. We have already learned that if the past did not exist, the present itself could not pass. Now we are told that 'The passing moment could never pass if it were not already past and yet to come - at the same time as being present.' Duration is a unity, but it is not merely a unity of past and present, as it might have seemed with [Henri] Bergson. It is a unity of past, present, and future. As a unity, each dimension is woven into the others. The future, the present, the past are involved, each in the others."

(Todd May, Gilles Deleuze: An Introduction. Cambridge: Cambridge University Press, 2005. 61.)

“...the idea of progress and hence the project of modernity already irrevocably entail the modern process of dynamization, and they are indeed themselves a reaction to the historical experience of social acceleration. Progress and accleration were indissolubly linked together 
from the very beginning. Therefore, the idea of reaching for the emergency break can only be consistently conceived with Walter Benjamin as a radical and revolutionary exit from history, as a revolution against progress, and hence in the end as a 'saving leap' out of modernity itself, i.e., equally out of the project and the process."

(Hartmut Rosa, Social Acceleration: A New Theory of Modernity. New York, NY: Columbia University Press, 2015. 321-2.)

"They were the cars at the fair that were whirling around her; no, they were the planets, while the sun stood, burning and spinning and glittering in the centre; here they came again, Mercury, Venus, Earth, Mars, Jupiter, Saturn, Uranus, Neptune, Pluto; but they were not planets, for it was not the merry-go-round at all, but the Ferris Wheel, they were constellations, in the hub of which, like a great cold eye, burned Polaris, and round and round it here they went: Cassiopeia, Cepheus, the Lynx, Ursa Major, Ursa Minor, and the Dragon; yet they were not constellations, but, somehow, myriads of beautiful butterflies, she was sailing into Acapulco harbor through a hurricane of beautiful butterflies, zigzagging overhead and endlessly vanishing astern over the sea, rough and pure, the long dawn rollers advancing, rising, and crashing down to glide in colourless ellipses over the sand, sinking, someone was calling her name far away and she remembered, they were in a dark wood, she heard the wind and the rain rushing through the forest and saw the tremors of lightning shuddering through the heavens and the horse - great God, the horse - and would this scene repeat itself endlessly and forever?"

(Malcom Lowry, Under the Volcano. Harmondsworth, Middlesex: Penguin Books, 1975. 335-336.)

"Too mature for new dawns, and having included too many centuries to crave more, all that remains for us is to wallow in the slag of civilizations. The march of time now seduces only the callow and the fanatic ..." 
(E. M. Cioran (Trans. Richard Howard), A Short History of Decay. New York, NY: Arcade Publishing, 2012. 119.)

"Sunflower [tournesol: turning to the sun] blindness, a conversion that twists the light and turns it upon itself to the point of dizziness, the blacking out of the one bedazzled, who sees himself go from brightness and clarity to even more clarity, perhaps to too much sun. This clairvoyance of the all-too-evident is Paul's madness. And one blames it on books, in other words, on the visibility of the invisible word: Festus cries, 'You are out of your mind, Paul! Books [grammata] are driving you mad!"”

(Jacques Derrida, Memoirs, in Virginia Burrus, "Creatio Ex Libidine: Reading Ancient Logos," in (Ed. Yvonne Sherwood and Kevin Hart), Derrida and Religion: Other Testaments. London and New York, NY: Routledge, 2005. 163.)

"As the line collapses between corporate fascism, authoritarian power, and democratic governance, repression intensifies and increasingly engulfs the nation in a toxic climate of fear and self-censorship in which both free speech and even critical thought itself are viewed as practices too dangerous to engage in. The NSA [National Security Agency], alone, has become what Scott Shane has called an 'electronic omnivore of staggering capabilities, eavesdropping and hacking its way around the world to strip governments and other targets of their secrets, all while enforcing the utmost secrecy about its own operations. It spies routinely on friends as well as foes.' Intelligence benefits are far outweighed by the dangers of illegal use of the Internet, telecommunication companies, and stealth malware for data collection and government interventions that erode civil liberties and target individuals and groups that pose no threat whatsoever to national security."

(Brad Evans and Henry A. Giroux, Disposable Futures: The Seduction of Violence in the Age of Spectacle. San Francisco, CA: City Lights Publishers, 2015. 204-5.) 


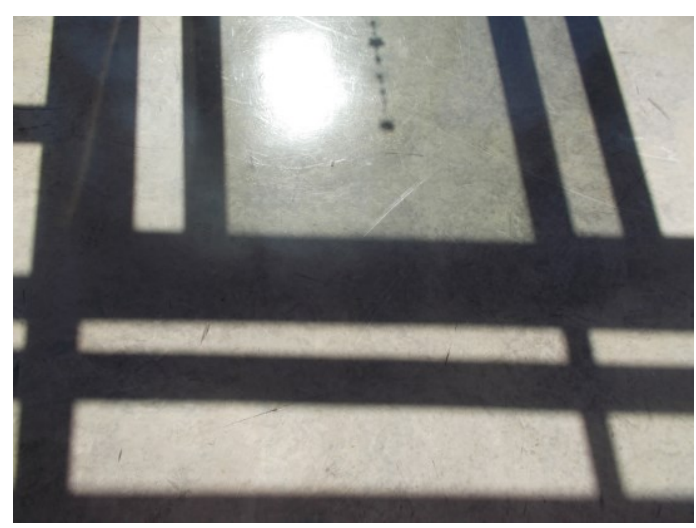

Shadows on a Floor, Halifax House, August 5, 2015.

"A play of light arrests the reader's attention: ecstatic instant, a spark of insignificance. This fragment of the unknown introduces a silence into the hermeneutic medley. Thus, little by little, common everyday life begins to seethe with disturbing familiarity - a frequentation of the Other."

(Michel de Certeau, Mystic Fables, Volume I, The Sixteenth and Seventeenth Centuries, in Greenstein, Roads to Utopia 125.)

"The paradoxical entity shines with a singular brilliance. It is what is fascinating in structuralist theory because it is like a line of flight, an evasion, or an errant liberty, by which one escapes the positivism of legalized beings. In the somber opacity of the combinatory ensemble, it is like a window. The paradoxical entity is a clear singularity. But this clarity equally plunges the whole Structure into confusion, for it is ultimately impossible to render this singularity really distinct. Constantly circulating - like the slipper or handkerchief passed around in certain games - it is always oblique: it is a presence made of absence, a number woven out of vacuity, an active zero, a signifier that does not signify. This means that thought intuits here the clear-confused and leads away from 
disjunctive separation, in opening up a breach toward univocity. But this also means, with regard to the sense produced by the structure, that thought pays the price of nonsense as the condition for this production."

(Alain Badiou, Deleuze: The Clamor of Being. Minneapolis, MN: University of Minnesota Press, 1999. 38, 8.)

"By identifying with the sun the poet rejects the cardinal categories of thought and at the same time thought itself; he returns to the lowly cities to look at people and their agitations through the sun's eyes, from the point of view of nonlife, of non-thought, of non-knowledge, and, finally, nonbeing. If he preserves the 'divine nothingness that drenched his heart,' he will use it to dehumanize men, to grasp them not as they think they are or live but as they are, that is, in that original non-sense whose surface has not even been scratched by their futile significations."

(Jean-Paul Sartre (Trans. Carol Cosman), The Family Idiot: Gustave Flaubert, 1821-1857, Volume 5. Chicago, Ill: University of Chicago Press, 1994. 335.)

"My theory stands as firm as a rock; every arrow directed against it will quickly return to the archer. How do I know this? Because I have studied it from all sides for many years, because I have examined all objections which have ever been made against the infinite numbers, and above all because I have followed its roots, so to speak, to the first infallible cause of all created things."

(Georg Cantor, German mathematician, in Armand Singh, The Woman Who Thought She Was a Planet. Shahpur Jat, New Delhi: Zubaan, 2009. 58.)

"The sun on this rottenness focused its rays

To cook the cadaver till done,

And render to Nature a hundredfold gift

Of all she had united in one." 
(Charles Baudelaire, "Reversibility," in (Trans. James McGowan), Charles Baudelaire: The Flowers of Evil. Oxford and New York, NY: Oxford University Press, 1998. 91.)

"That the Face of the Sun will by Degrees be encrusted with Effluvia, and give no more Light to the World. That, the Earth narrowly escaped a Brush from the Tail of the last Comet, which would have infallibly reduced it to Ashes; and that the next, which they have calculated for One and Thirty Years hence, will probably destroy us. For, if in its Perihelion it should approach within a certain degree of the Sun, (as by their Calculations they have Reason to dread) it will conceive a Degree of Heat ten Thousand Times more intense than that of red hot glowing Iron; and in its Absence from the Sun, carry a blazing Tail of Ten Hundred Thousand and Fourteen Miles long; through which if the Earth should pass at the Distance of one Hundred Thousand Miles from the Nucleus, or main Body of the Comet, it must in its Passage be set on Fire, and reduced to ashes."

(Jonathan Swift, Gulliver's Travels. Mineola, NY: Dover Publications, 1996 118.)

"Multicolored and poetic, that enchanted awakening after an unearthly night restored me to my old self. I felt as if I had escaped a frightful nightmare, and I had by me, in my arms, beneath my hand, a sweetly stirring breast, a breast of lily and roses, so youthful, so delicate and so pure that merely to brush it with one's lips was enough to make one fear one had bruised it.

I wanted to see the Countess again. I found her in her salon, asleep, sprawled on the fragile chaise lounge. She was all in an ignoble heap, her face distorted, her body unclean, polluted. Like a drunken woman, flung into a gutter, she seemed to be fermenting in her lewdness.

'Ah, let us leave this place!' I cried. 'Let us be gone, Fanny, an end to this vile interlude."” 
(Alfred De Musset, Gamiani, Or Two Nights of Excess. New York, NY: Harper Perennial, 2007. 53-55.)

"Between the dawn and the night there is an abyss of agonies, of lights, of cares; the face that looks at itself in the wasted mirrors of the night is not the same.

The furtive today is tenuous and is eternal; Expect no other Heaven, and no other Hell."

(Jorge Luis Borges, qtd. in William Egginton, The Theater of Truth: The Ideology of (Neo)-Baroque Aesthetics. Stanford, CA: Stanford University Press, 2009. 101.)

"It is a duty which the United States owes to mankind, to assert inflexibly its title to its proper territory, to guard it religiously from all encroachments by the powers of Europe, that it may become the home of men living under democratic institutions, framed after the pattern of our own ... We have no right to give up a foot of the domain which Providence has put under our charge, to the evils of a colonial, or an aristocratic government. We should early mark out our just limits, and take early measures to hold them sacred against the invasion of the old world."

(William Cullen Bryant, qtd. in Albert Boime, The Magisterial Gaze: Manifest Destiny and American Landscape Painting c. 1830-1865. Washington and London: Smithsonian Institution Press, 1991. 15.)

"The 'westward journey' motif also potentially initiates a number of intertextual links, including Dante's use in the Commedia of the welldeveloped medieval topos of the translatio imperii, of movement from east to west - related to the westward movement of Aeneas from Troy to Rome - as a fundamental metaphor for history itself. 'Modelled on the movement of the sun from east to west, this doctrine is conventionally 
based on the analogy between the duration of the day and the totality of history.' Thus 'The sun is the foundation of history, its radical metaphor."”

(Keith M. Booker, Joyce, Bakhtin, and the Literary Tradition: Towards a Comparative Cultural Poetics. Ann Arbor, MI: University of Michigan Press, 1998. 147.)

"Blessed sun, who hast the strength to seek us out, even down to the graves under the trees..."

(Hjalmar Söderberg, Doctor Glas. New York, NY: Anchor, 2002. 71.)

"We are, not unlike Socrates' cave dwellers, trapped in a world of delusions. But in this case, rather than go out to see the sun (the ultimate delusion, perhaps), we have to burrow deeper into the recesses of the cave. If we have no choice but to go deeper, let us go together, fighting and resisting every step of the way. We may, indeed must, have no hope, but in that hopelessness we can, just maybe, fight to see another day."

(Martel, Textual Conspiracies 258.)

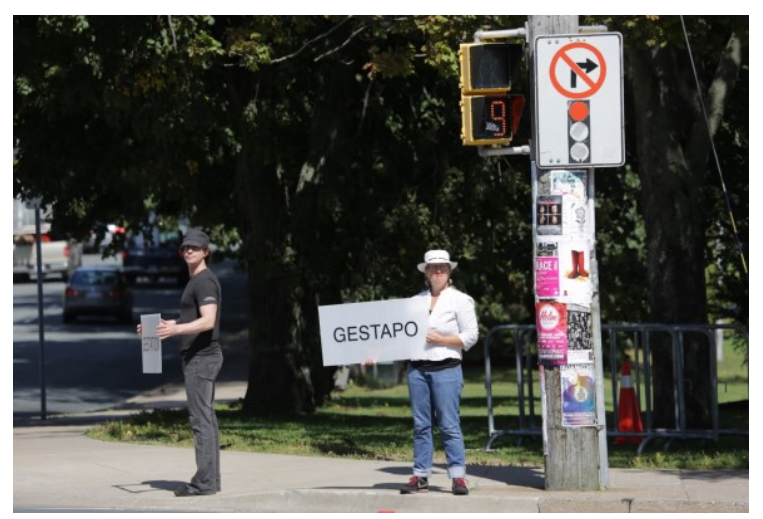

